\author{
Iva Mršić Felbar \\ Sveučilište u Zagrebu, Katolički bogoslovni fakultet, Vlaška 38, HR-10000 Zagreb \\ iva.mrsicfelbar@gmail.com
}

\title{
Jesmo li slobodni umrijeti?
}

\section{Neki aspekti tematiziranja smrti i slobode u suvremenoj katoličkoj eshatologiji}

\begin{abstract}
Sažetak
Članak se osvrće na problematiku smrti kao središnjeg problema svake pa tako i katoličke eshatologije. Smrt kao fenomen i antropološka danost oblikuje začetke eshatologije Staroga zavjeta, zaoštrujući svoj teološki iskaz u novozavjetnoj teologiji crucis. Tijekom povijesti teološke misli, teologija smrti ostala je unutar okvira njezina tumačenja kao posljedice grijeha i neželjenog usuda, pri čemu je izostala njezina pozitivna poveznica sa slobodom. Tek zahvaljujući određenim suvremenim pristupima koji smrt stavljaju u izravan odnos sa slobodom (Moltmann, Rahner, Boros), smatrajući da je čak možemo promatrati kao svjestan čin pojedinca, smrt i sloboda, iako naizgled suprotstavljene, postaju kategorije koje se, teološki gledano, međusobno transformiraju. Zaključno članak pokušava u svjetlu izdvojenih suvremenih eshatoloških rasprava odgovoriti na pitanje jesmo li slobodni umrijeti $i$ svjesnost o smrti smjestiti u kontekst slobode $i$ života, a ne njima nasuprot.
\end{abstract}

Ključne riječi

eshatologija, smrt, sloboda, Stari zavjet, čovjek

\section{Uvod}

\section{Status quaestionis}

Smrt utječe na oblikovanje života jer smo u manjoj ili većoj mjeri svjesni vremenske ograničenosti naše egzistencije. Sama spoznaja da je smrt činjenica koja nas se nužno tiče i donekle lebdi ponad života kao Damoklov mač, utječe na religijsko obrazloženje onoga što (moguće) slijedi nakon nje, kao i na odnos spram života kojega živimo i unutar kojega stvaramo. Smrt umnogome oblikuje ljudski život, premda nismo skloni o njoj (na taj način) misliti. U različitim fazama života posjedujemo različitu svijest o neizbježnosti umiranja, a isto tako u različitim etapama života drugačije se odnosimo prema slobodi kao bitnoj odrednici svojega biti čovjekom. Pomisao na smrt kreće se nerijetko od sfere tabua pa sve do ponegdje pretjeranog teološkog romantiziranja i vjerničke sigurnosti da je riječ samo o prijelazu s ovoga svijeta u onaj vječni, bolji život koji u nama budi iskonsku čežnju za izgubljenim rajem.

No, pitanje je, bi li koncept religija bio baš ovakav da nismo primorani suočiti se sa smrću. ${ }^{1}$ Eshatologija ${ }^{2}$ se tradicionalno više bavila onime što slijedi nakon smrti, ali, paradoksalno, sve do čega je čovjek zapravo došao baveći se preispitivanjem eshatona, rezultat je postojanja smrti. Naime, nagnuće da uvijek iznova osmišljavamo svoj život, da ga činimo ispunjenim nasuprot ništavilu smrti ili da ga baš u inat tome živimo isprazno, na taj način (krivo) koristeći svoju slobodu, jedan je od načina na koji se suočavamo s tim pita- 
njem. Smrt i sloboda predstavljaju okosnicu eshatologije. Smrt je tu kao poticaj na postavljanje pitanja o kraju, njegovu (be)smislu, a sloboda kao prostor odgovora na nj. Smrt je neizbježna, no, jesmo li unatoč tom usudu slobodni umrijeti? Bez obzira odgovorimo li na to pitanje potvrdno ili niječno, ostaje pritom za razmotriti važnu vezu između smrti i slobode koju nalazimo u nekim aspektima suvremene eshatološke misli.

\section{Smrt kao jezgra katoličke eshatologije}

Svako eshatološko pitanje počinje s pitanjem čovjekove smrtnosti i prolaznosti. Činjenica smrti predstavlja pravo teološko pitanje, ${ }^{3}$ ne samo u smislu propitkivanja vlastite, ljudske egzistencije, nego i one božanske. Nadalje, smrt nas direktno upućuje na pitanje o uskrsnuću koje predstavlja središte kršćanske vjere. Kako uopće misliti smrt koja je tradicionalno bila vezana uz grijeh (osobito uz tumačenje istočnoga grijeha), ${ }^{4}$ kao čin u koji, bez obzira na karakterističan usud i neizbježnost smrti, možemo ići slobodni/oslobođeni? Teološki gledano, smrt nastupa onda kad nestaje mogućnost povratka ${ }^{5}$ (tako, primjerice, kliničku smrt u teološkom smislu ne možemo promatrati kao takvu). U tom smislu, biblijska objava na taj način progovara o fenomenu smrti, promatrajući je prvenstveno kao životnu danost i prikazujući Boga kao apsolutnog vladara života i smrti. Osim toga, Biblija ističe život kao najveći Božji dar i najveću vrijednost (usp. Job 42,17; 2 Mak 7,23; Mudr 3,1), a uz to je posve logično da pored života spominje smrt kao njegovu izravnu ugrozu. Ovdje ćemo ukratko promotriti na koje se sve načine može govoriti o smrti kao svojevrsnom nukleusu katoličke eshatologije.

\subsection{Biblijski temelji i starozavjetni razvoj}

Smrt je bitna pretpostavka osobne eshatologije, no isto tako i one opće, kozmičke. Kao svoj prvi izvor ${ }^{6}$ katolička eshatologija uzima Bibliju i prati njezin razvoj koji se dinamički i kvalitativno mijenja od abrahamovskih vremena pa sve do novozavjetnog obrata u Isusu Kristu. Ovdje prikazani kontekst biblijskog pristupa tematici smrti iz koje se kasnije razvija i teologija smrti, važan je za kasnije razumijevanje relacije između kategorija smrti i slobode.

Promatrajući razvoj katoličke eshatologije, ne bismo mogli na prvi pogled utvrditi da je njezin razvoj usredotočen na fenomen smrti. Dapače, ako bismo mogli izdvojiti stožerni biblijski pojam, to bi prvenstveno bio život, ${ }^{7}$ a ne smrt. Počev od starozavjetne prapovijesti, u Bibliji možemo iščitati da se Izraelac nada poglavito trima stvarima: dugom životu, potomstvu i Božjoj pomoći (ne ulazeći ovdje u kompleksnost razvoja poimanja ideje božanstva), odnosno želi biti pokopan s ocima, ${ }^{8}$ čime je ostvarena povezanost s klanom, plemenom i onkraj granice smrti. To je vidljivo i u obećanjima danim Abrahamu, u kojima mu je Bog obećao zemlju i veliko potomstvo (usp. Post 12,1-4). Ono što je priječilo realizaciju tih triju objekta nadanja, dakle, prerana smrt, život bez potomstva ili pokop u tuđoj zemlji bili su motivom žalosti, a ne toliko smrt kao takva. Naime, najstariji starozavjetni pisci još ne razmišljaju o usudu nakon smrti, a eshatološka nada, kako je rečeno, bila je usmjerena na ovozemaljske sadržaje. U prvom je planu vrednota života. No, kako to obično biva, kušnje na koje je bio stavljen izraelski narod, umnogome su protresle ovakav način promišljanja o smrti (i o životu!) te su počele, zajedno s procesom individualizacije eshatološke nade koju možemo pratiti kod proroka, stavljati u pitanje smisao smrti. 
»U okviru starozavjetne antropologije smrt nastupa odmah čim Jahve oduzme čovjeku životni dah (hebr. nešāmâ ili ruah) (usp. Job 34,14; Ps 104,29; 146,4). «9

Stari zavjet nam stavlja pred oči smrt kao prirodnu činjenicu $(1 \mathrm{Kr} 2,2)$ i kao kaznu za grijeh (Post 2-3; Sir 25,24; Mudr 2,24). Biblijsko shvaćanje smrti pretpostavlja sljedeće: psihološki element u kojem smrt zaustavlja životnost

Postoje autori, primjerice David Bentley Hart, koji tvrde da ne postoje izravni dokazi koji ukazuju na povezanost religioznog impulsa s nadom u onostranost. Kad je riječ o Starome zavjetu, tu se konkretno s ovim autorom slažemo, o čemu će više biti riječi u nastavku članka. Usp. David Bentley Hart, »Death, Final Judgment, and the Meaning of Life «, u: Jerry L. Walls (ur.), The Oxford Handbook of Eschatology, Oxford University Press, New York 2008., str. 476-492, ovdje str. 479.

2

Eshatologija je dogmatski traktat, odnosno teološka disciplina koja se bavi tzv. posljednjim stvarima (grč. eshata $=$ posljednji), koje podrazumijevaju smrt, sud, raj, pakao, čistilište, povratak Krista, uskrsnuće mrtvih i svršetak svijeta, a može biti individualna (tiče se pojedinca) ili kolektivna (tiče se čovječanstva u cjelini). Budući da se ovdje referiramo, pored novozavjetne, i na starozavjetnu eshatologiju koja ima svoje specifičnosti, napomenut ćemo da u Starome zavjetu još ne postoji sadržaj vjerovanja u ono što u užem smislu nazivamo eshatologijom. Naime, stari Hebreji nisu razmišljali u apstraktnim pojmovima pa u tom smislu nisu niti mogli pojmiti što bi označavao konačni, apsolutni završetak, niti su od svojeg promišljanja stvorili spekulativan, sustavan nauk kakvog nalazimo puno kasnije kad su se vjerski sadržaji sistematizirali. Više o temi biblijske eshatologije vidi: Adalbert Rebić, »Vjera u prekogrobni život u Starome zavjetu i u kasnom židovstvu. Starozavjetna (individualna) eshatologija«, Bogoslovska smotra 52 (1982) 3, str. 338-366; Adalbert Rebić, »Biblijska eshatologija«, Bogoslovska smotra 73 (2003) 1, str. 71-100; Anđelo Maly, »Neke crtice o starozavjetnoj eshatologiji«, Bogoslovska smotra 87 (2017) 2, str. 303-326; Ivan Šporčić, »'Eshaton' u Starom zavjetu. Skica za starozavjetnu biblijsku eshatologiju«, Riječki teološki časopis 9 (1997) 1, str. 41-60

Usp. Silvano Zucal, La teologia della morte in Karl Rahner, EDB, Bologna 1982., str. 43.

Usp. Franz Courth, Kršćanska antropologija. Bog - čovjek - svijet, prev. Marijan Cipra, Ivan Zirdum, Forum bogoslova, Đakovo 1998., str. 70-76; Ladislav Nemet, Kršćanska eshatologija, Kršćanska sadašnjost, Zagreb 2002., str. 70-74.

5

Usp. L. Nemet, Kršćanska eshatologija, str. 69

Sveto pismo svakako predstavlja prvi i najvažniji izvor o promišljanju kršćanskih eshatoloških sadržaja i za analizu njegova razvoja. No, treba napomenuti da neki autori uz Sveto pismo ističu temelje kršćanske eshatologije među kojima su antropološki i kristološki. Među antropološke temelje spadaju svijest o smrtnosti, uvjerenje da smrt nema posljednju riječ u ljudskoj egzistenciji, pitanje pravednosti i pitanje o tome hoće li svi imati isti kraj, te uvjerenje u postojanju smisla svega stvorenoga. S druge strane, kristološki temelji pružaju odgovor na antropološke, fundirajući ih u Kristovoj osobi, odnosno njegovom pashalnom otajstvu. Tako se ističe da je Bog sama pravednost, da u Isusu Kristu povijest dobiva smisao te da ni u činjenici smrti nismo sami jer je Krist umro za nas. Usp. L. Nemet, Kršćanska eshatologija, str. 7-10.

U Bibliji se za život rabi izraz hajjah (grč. zoé) i nefeš (grč. psihé), što ga smješta u ovisnost o disanju, krvi i pokretnosti. Premda najveće dobro, prekratko traje pa je u tom smislu duboka starost blagoslov (Job 42,17). Život se teološki prvotno promatra kao dar Božji jer se u njemu jasno očituje kontingencija i stvorenost, a i sam Bog je u odnosu na život - živi Bog. Osim što nam daje život, on ujedno i poziva na vječni život. Život je kruna ovozemaljskog stvaranja, a vječni život kruna onostranosti. No, Biblija svjedoči o krhkosti života u povezanosti s činjenicom smrtnosti, a Bog koji udahnjuje život, isto ga tako ima moć oduzeti. On, međutim, ne stvara čovjeka da bi ga usmrtio (Ez 18,22). Biblijska teologija uočava svezu između grijeha i smrti, s vremenom shvaćajući da i umirući može pronaći život. Isus navješćuje život i u njemu se očituje život kojeg on suvereno posjeduje i daruje u izobilju. Krštenjem u njegovu smrt postajemo živima te učimo sudjelovati u njegovu pashalnom otajstvu, pružajući životu da proguta što je smrtno $(2$ Kor 5,4$)$ i odijevajući svoju raspadljivost u besmrtnost, što nužno iziskuje tjelesna smrt. Usp. »Život«, u: Xavier 
(nefeš) čovjeka, sociološki element prekida povezanosti sa zajednicom, povijesni element u kojem sa smrću prestaju svi odnosi (sociološki, politički, komunitarni odnosi), pa je u skladu s takvim poimanjem smrti u Starome zavjetu ona viđena u biološkom smislu kao prestanak života, u mitološkom smislu kao neka sila, te simbolički kao gubitak one radosti života za koju Jahve želi da postoji u zajedništvu s njime i njegovim savezom. Tako se spominje i napuštanje saveza kao svojevrsna smrt u smislu opiranja i suprotstavljanja Jahvi kao Bogu života (usp. Pnz 30,15). Takvoj smrti nasuprot, javlja se kod Izraelaca nada da će Jahve pobijediti smrt. ${ }^{10}$

Važnu ulogu u konkretizaciji eshatoloških sadržaja ima pojam šeola ${ }^{11}$ koji prvotno predstavlja starozavjetno uvjerenje da pokojnik ima trajnu egzistenciju, odnosno predstavlja objektivizaciju iskustva o samoj smrti (ne toliko o tome što postoji ili ne nakon nje), a osobito je tu prisutna zagonetka smrti u odnosu s otkupljenjem, čime se njezino razrješenje prepušta u konačnici Bogu. ${ }^{12}$

»Šeol je često u biblijskim tekstovima sinonim za smrt. «13

U šeol svi idu, bez iznimke (Ps 89,49), a Jahve jedini kao Gospodar života i smrti (Ps 30,4) može izbaviti pokojnika iz šeola, koji se, kao i smrt, smatra kao kazna za grijeh (Iz 14,2-21; Ez 32,17-32).

»Stanju smrti pripadaju tama (Job 10,21s; 17,13; 38,17; Ps 88,7.13; 143,3; čak vječna Ps 49,20), prah (Job 17,16;20,11; Ps 30,10; 146,4; Iz 26,19; Dn 12,2), šutnja (Ps 94,17; 115,17; Sir 17,27; Iz 38,18). Lišeni cjelokupne snage i vitalnosti (Iz 14,10) mrtvi se nazivaju refa 'im, skršeni. Oni su kao nepostojeći (Ps 39,14; Sir 17,28), borave u zemlji zaborava (Ps 88,13). « ${ }^{14}$

Sve se više, dakle, osobito u razdoblju nakon egzila, postavlja pitanje o usudu pojedinca zbog prisutnosti svijesti da podjednako umiru i dobri i zli te se na taj način upravlja pitanje Bogu o njegovoj pravednosti, moći i vjernosti. Tako i prije eksplicitnog govora o uskrsnuću, koje u Starome zavjetu, egzegetski gledano, nalazimo sa sigurnošću samo u Dn 12,2, iščitavamo prefiguracije vjere u uskrsnuće (usp. Ez 37; Hoš 6,2; Iz 25), unutar kojih možemo nazrijeti promišljanje o smrti koja će biti uništena, ali se još ne precizira način na koji će se to dogoditi. Dakako, treba pritom imati na umu da se o smrti i uništenju ne govori uvijek doslovce, već i simbolički. No, u svakom slučaju postaje vidljivo da starozavjetne pisce sve više muči prolaznost u smislu postavljanja problema oko ishoda čovjekova života u onostranosti, te se prvotni objekti nadanja smješteni u ovostrano relativiziraju. Dug život, brojno potomstvo i pokop u vlastitoj zemlji nisu više ultimativna dobra jer je pogled sad sve više usmjeren na eshaton, odnosno na onostranost - onkraj smrti. Dakako, nije naodmet primijetiti da je upravo odlazak u sužanjstvo, dakle, ograničavanje i oduzimanje slobode Izraelcima bio poticaj za promišljanje o tome završavaju li svi ljudi nakon smrti jednako ili je onostranost ipak mjesto očitovanja Božje pravednosti. Također, treba istaknuti da starozavjetni pisci ne razmišljaju o eshatonu kao filozofskom pitanju granične situacije smrti i konačnoga (u)suda, već to pitanje vezuju uz vjeru u Boga stvoritelja i uzdržavatelja, koji je nadasve pravedan. U tom se kontekstu javlja pitanje o tome hoće li svi skončati isto ili ipak Bog kao sama pravednost ima zadnju riječ.

Razvidno je da eshatologija iz Biblije crpi pristup smrti kao (prirodnom) fenomenu, ali ujedno izbjegava svođenje teologije na antropologiju. Stoga, smrt kao fenomen i životna danost predstavlja samo temelj za daljnja razmišljanja koji nas dovode do teologije smrti. 


\subsection{Novozavjetni naglasci}

Rasprave oko onostranosti koje se još uvijek obrađuju u starozavjetnom kontekstu s aspekta polemike, odražavaju se i u vrijeme Isusova propovijedanja kraljevstva Božjeg. Naime, u raspravi sa saducejima (usp. Mk 12,18-27) vidljivo je da im Isus spočitava da ne poznaju silu Božju i da Bog nije Bog mrtvih, nego živih. Biblija nam svjedoči da smrću umire čitav čovjek, ne samo njegovo tijelo. Sav čovjek biva uništen smrću. Uskrsnućem, s druge strane, zahvaljujući Kristovu pashalnom otajstvu i spasenjskom zahvatu, postoji mogućnost ponovnog zadobivanja života u punini. Isus naviješta radosnu vijest Kraljevstva Božjega, a ono sámo u svojoj sintagmi označava život u kvalitativnom smislu, u punini. Isus donosi takav život i omogućuje ga i nama kroz svoju smrt koju podnosi u slobodi. Kraljevstvo Božje, ${ }^{15}$ temelj Isusova navještaja, predstavlja navještaj o životu vječnom i činjenicu da pobjeda smrti znači radosnu vijest.

Leon-Dufour (ur.), Rječnik biblijske teologije, prev. Mate Križman, Kršćanska sadašnjost, Zagreb 1993., str. 1560-1567; »Život«, u: Luciano Pacomio (ur.), Enciklopedijski teološki rječnik. Sveto pismo, povijest, duhovnost, fundamentalna teologija, dogmatika, moral, ekumenizam, religije, Aldo Starić (ur.), prev. Slavko Antunović et al., Kršćanska sadašnjost, Zagreb 2009., str. 1326-1327.

8

Usp. L. Nemet, Kršćanska eshatologija, str. 22-23.

9

A. Rebić, »Vjera u prekogrobni život $u$ Starome zavjetu i u kasnom židovstvu«, str. 352.

10

Usp. ibid., str. 352-353.

11

Šeol se prvotno shvaćao kao boravište mrtvih koje se zamišljalo pod zemljom, kao život sjena koji je odvojen od Boga i života. Pojavljuje se 66 puta u SZ-u, od toga najviše u Psalmima, Jobu i Mudrim izrekama. U šeolu nema Boga (Ps 139,8-12) jer oni nemaju odnos s Bogom (Ps 115,17). Smrt tako najviše označava manjak, odnosno izostanak odnosa i s Bogom i s drugim ljudima. U početku još nije postojalo razlikovanje između dobrih i zlih (Job 3,19; Prop 2,15), a koje se počinje uvoditi (Lk 16,22-24) s izjednačavanjem šeola $\mathrm{s}$ gehenom (hebr. ge Hinnom). Usp. Hans Urs von Balthasar, Mysterium Paschale. Sveto trodnevlje smrti, pokopa i uskrsnuća našega Spasitelja, prev. Marko Lončar, Kršćanska sadašnjost, Zagreb 1993., str. 131-139.

12

Usp. »Šeol«, u: Karl Rahner, Herbert Vorgrimler, Teološki rječnik, prev. Franjo Gruić, Ivan Zirdum, Forum bogoslova, Đakovo 1992., str. 590.
13

A. Rebić, »Vjera u prekogrobni život u Starome zavjetu i u kasnom židovstvu«, str. 351.

14

H. U. von Balthasar, Mysterium Paschale, str. 132.

15

Izraz kraljevstvo Božje u obliku Yhwh malak (Jahve kraljuje) nalazimo već u Starome zavjetu kao ispovijest vjere u Jahve, dok apstraktni izraz malkut Yhwh u onodobnoj kulturi izražava Božje vrhovništvo i vlast. S druge strane, »božansko kraljevsko dostojanstvo jest predodžba koja je zajednička svim religijama starog Istoka« (Rječnik biblijske teologije, str. 441). Židovski narod često je očekivao figuru Mesije u formi kralja, a upravo je sadržaj te ideje radosna vijest u Starome zavjetu - da Bog kraljuje! Iz Novoga je zavjeta vidljivo da je riječ o kompleksnom pojmu čiju narav samo Isus Krist poznaje i objavljuje na zagonetan način, u prispodobama, ne bi li tako ostavio otvorenim njegovo značenje. Upoznati kraljevstvo, znači upoznati Isusa i njegovu osobu. Uskrsnuće označava Isusovo kraljevsko ustoličenje, dok će na kraju vremena, o paruziji, svoje kraljevstvo predati Ocu. Govor o kraljevstvu Božjem važno je za poimanje eshatoloških sadržaja, osobito u njihovoj napetosti između već i još ne, te načinu na koji suvremena eshatologija promišlja sadašnjost. Naime, govor o Božjem kraljevstvu ima kritičku funkciju za Crkvu i društvo (usp. Teološki rječnik, str. 254) jer se ono ne identificira ni s Crkvom ni s državnim/kraljevskim ustrojstvom koje bi pripadalo ovozemaljskoj političkoj sferi, već je, štoviše, njezinom kritikom jer je na nju nesvodivo. Ono ima i eshatološko obilježje (usp. Marcello Semeraro, »Kraljevstvo Božje«, u: L. Pacomio, Enciklopedijski teološki rječnik, str. 539-541). 
Dakle, od početnog nespominjanja smrti, barem ne u strogo eshatološkom kontekstu, pa sve do stavljanja u pitanje njezina fenomena kao granične situacije, pratimo starozavjetno tematiziranje smrti koja će svoj vrhunac imati u novozavjetnoj smrti Boga na križu, a koje će posljedično uzdrmati i preokrenuti svaki govor o smrti te pokazati da »najdublja čovjekova jezgra, dakle, teži na apsolutan način za nadvladavanjem smrti«. ${ }^{16}$

Pastoralna konstitucija o Crkvi u suvremenom svijetu Drugoga vatikanskog sabora Gaudium et spes smrt definira kao najveću zagonetku ljudske egzistencije (GS 18), ${ }^{17}$ no ta zagonetka, teološki gledano, dobiva svoj odgovor u pashalnom misteriju ${ }^{18}$ Isusa iz Nazareta, Krista. Smrt predstavlja vrhunac Isusove egzistencije utjelovljenja koja je od početaka u Novome zavjetu shvaćena kao utjelovljenje Boga, a samim time i vrhunac njegove objave kao Boga ljubavi. On svoju smrt, bez obzira na napete povijesne okolnosti koje mu zbog njegove revolucionarne poruke $\mathrm{u}$ više navrata rade o životu, ${ }^{19}$ ipak prihvaća slobodno te je kao biljeg grijeha uništava - smrću i uskrsnućem.

»Naime, Kristovo je uskrsnuće u svojoj istinskoj biti (a ne samo po nekakvom juridičkom Božjem prihvaćanju) događaj u kojem Bog ne samo neopozivo prihvaća stvorenje kao svoju vlastitu stvarnost nego to stvorenje, pobožastvenjujući ga, tako proslavlja da se ta proslava događa i probija kao posvemašnje prihvaćanje ove božanske prihvaćenosti od strane samog a slobodnog stvorenja. $\ll^{20}$

Kristova je nasilna, stravična i okrutna smrt na križu suprotstavljena još većoj milosti i nježnosti Božjoj kojom on spašava čovjeka. Tako paradoksalno, naslanjajući se na sv. Augustina, možemo reći da je Isus iz Nazareta svojom smrću usmrtio smrt. ${ }^{21}$ Naime, on nije samo podnio smrt, nije je samo u slobodi prihvatio i preuzeo sve posljedice koje iz nje proizlaze, nego je svojom smrću i protestirao protiv smrti uopće. Njegova je smrt krik protiv svih stanja nedostojna čovjeka: grijeha, bolesti, usamljenosti, marginalizacija, etiketiranja. Njegova je smrt protest protiv svih ubijanja. Ono što je pritom revolucionarno jest da njegova revolucija nije provedena nasilno - mačem i ratom - već ljubavlju koja se dala usmrtiti da bi donijela život u uskrsnuću. Ne zaboravimo pritom da njegov put prema smrti započinje činom utjelovljenja koji je jednako tako revolucionaran (Bog postaje čovjekom!). On, dakle, prihvaća prolaznost, vremenitost, slabost i krhkost ljudske egzistencije, te se tako, iako bez grijeha, podlaže njezinim zakonitostima kao pravi čovjek. Smrt Isusa Krista zadnja je posljedica njegova utjelovljenja.

Sablazan i skandal križa proteže se i na smrt. Ona znači poništenje, ništavilo i gubitak, ali je pritom, baš kao križ, prepuna suprotnosti. Naime, kao što i križ od prokletstva postaje blagoslovom u soteriološkome smislu, tako i smrt, iako u njoj sve gubimo, postaje jedinim putem da sve (za)dobijemo. To je, pavlovski rečeno, ludost i paradoks smrti kojoj prethodi ludost i sablazan križa. Život se, uostalom, često promatra kao nešto što je od svojih početaka obilježeno križem. ${ }^{22} \mathrm{~J}$. Ratzinger ističe da je teologija smrti za njega »nastojanje oko realistične antropologije $\ll,{ }^{23}$ odnosno da nas konačnost i suočavanje sa smrću svakodnevno ugrožava, te da se naša ograničenost odražava u patnji. ${ }^{24}$

»Smrt u konačnici posve raskrije aporetičnost ljudskog opstanka, jer slobodu, uza svu 'apsolutnost', naposljetku neizbježno dostigne zakon prirodnosti. $\ll^{25}$

Drugim riječima, čim se rodimo - moramo umrijeti. Gdje je u tome sloboda?

Biblija opisuje smrt kao nešto pred čime čovjek osjeća strah. Nadalje, ona, iako prirodna, ipak ostaje posljedicom grijeha: 
»Zbog toga, kao što po jednom čovjeku uđe u svijet grijeh i po grijehu smrt, i time što svi sagriješiše, na sve ljude prijeđe smrt.« (Rim 5,12)

»Smrt znači rastaviti zemaljski šator, skinuti odijelo, udaljiti se od tijela. « ${ }^{26}$

To je ono što biblijski pisci glede smrti uočavaju. Međutim, jako je važno da se biblijski pogled ne zaustavlja samo na površnom pogledu smrti kao fenomena i stvaranju njezine veze s grijehom, već je od naravne smrti puno gora ona vječna, odnosno, Novi zavjet posebno ističe način umiranja koje naziva »umrijeti u Gospodinu«:

»Blaženi mrtvi koji umiru u Gospodinu.« (Otk 14,13)

Tko umire tako, »neće mu nauditi druga smrt« (Otk 2,11). Smrt na taj način postaje 'krštenjem' za novi, vječni život. ${ }^{27}$ Kršćanski život bi stoga trebao, da bi bio život u punini, biti ispražnjen - sebičnosti, usmjerenosti na vlastito dobro - i postati više kristolik. Na taj način smrt prestaje biti viđena kao neprijatelj, a postaje više putokazom u život onkraj smrti koji za kršćanina

16

Tommaso Stancati, »Smrt«, u: L. Pacomio (ur.), Enciklopedijski teološki rječnik, str. 1066.

17

Gaudium et spes je pastoralna konstitucija Drugog vatikanskog sabora koja od svih njegovih dokumenata najviše progovara o eshatološkim temama, naglašavajući pritom antropološku dimenziju unutar koje problematizira: stvarnost smrti, konačno uništenje, neprihvaćanje kraja, instinkt za životom i nemoć ljudskih snaga, te je potom problematizira usporedno s onom kristološkom. Usp. Renzo Lavatori, Gospodin će doći u slavi. Eshatologija u svjetlu Drugog vatikanskog sabora, prev. Ivana Carmen Karačić, Kršćanska sadašnjost, Zagreb 2011., str. 43-50.

18

Drugi vatikanski sabor u dogmatskoj konstituciji Lumen gentium ističe pashalni misterij kao temelj eshatologije, a uz njega ističe još pneumatološku dimenziju eshatologije, ekleziološku značajku, kozmičku otvorenost, perspektivu zajedništva i trinitarni vid. Usp. Drugi vatikanski koncil, »Lumen gentium. Dogmatska konstitucija o Crkvi (21. XI. 1964.)«, u: Drugi vatikanski koncil, Dokumenti. Drugi vatikanski koncil, Kršćanska sadašnjost, Zagreb 2008., br. 48.

19

Usp. Jürgen Moltmann, Raspeti Bog. Kristov križ kao temelj i kritika kršćanske teologije, prev. Željko Pavić, Ex libris, Rijeka 2008., str. 127-168; Ivan Karlić, »Osuda i smrt Isusa iz Nazareta, Krista«, Bogoslovska smotra 74 (2004) 3, str. 859-888; Joaquín Losada, »Kako je Isus shvatio svoju smrt?«, u: Stjepan Kušar (prir.), Isus Krist Bogočovjek i Spasitelj, Kršćanska sadašnjost, Zagreb 1997., str. 81-88.
20

Citat preuzet iz: Karl-Heinz Weger, Uvod $u$ teološku misao Karla Rahnera, Kršćanska sadašnjost, Zagreb 1986., str. 132.

21

St. Augustine, Tractate of the Gospel of John 1-10. The Fathers of the Church, sv. 78, prev. John W. Rettig, The Catholic University of America Press, Washington D.C. 1988., str. 78 (Tract. 2. 16, 2.). Ove su riječi ujedno prisutne i u uskrsnom predslovlju: »Svojom smrću uništio je našu smrt, a svojim uskrsnućem on je obnovio naš život.« - Prema: Stjepan Kušar, »Vazmeno otajstvo i kršćanska obitelj«, Obnovljeni život 44 (1989) 6, str. 510-523, ovdje str. 516.

22

Usp. H. U. von Balthasar, Mysterium Paschale, str. 71-72.

23

Benedikt XVI. [Joseph Ratzinger], Eshatologija. Smrti $i$ vječni život, prev. Ivan Ivanda, Verbum, Split 2016., str. 262.

24

Usp. Benedikt XVI. [J. Ratzinger], Eshatologija, str. 262.

25

Johann Baptist Metz, Krajolik od krikova. O dramatici teodicejskog pitanja, prev. Roman Karlović, Ex libris, Rijeka 2011., str. 113.

26

Candido Pozo, Eshatologija, prev. Anto Šarić, Vrhbosanska katolička teologija, Sarajevo 1997., str. 392.

27

Usp. C. Pozo, Eshatologija, str. 393. 
predstavlja život u Bogu. U tom se smislu otvara prostor za povezivanje smrti i slobode.

Vidljivo je da su starozavjetni pisci, s jedne strane, bili svjesni da je smrt dio života i u neku su je ruku prihvaćali kao nešto naravno, kao nešto što su usvajali putem životnog iskustva, kao fenomenološku zbilju, dok, s druge strane, nalazimo tekstove koji smrt vezuju uz grijeh (usp. Mudr 2,23-24; Sir $25,24)$ i čovjekovu prolaznost u negativnom kontekstu. Takva smrt od koje čovjek strepi, pa čak i bježi, postaje impulsom za eshatološko promišljanje, kako o samoj smrti kao početku i graničnoj situaciji svega onostranoga, tako i za eshatološke stvarnosti koje su onkraj same smrti, što je osobito prisutno u Novome zavjetu. Smrt je biblijskom piscu bila nagnuće da postavi pitanja koja se tiču eshatoloških stvarnosti, kao i da na taj način reflektira pitanje (zlo)uporabe slobode na koju pravedni Bog ima svoj konačni odgovor onkraj granica smrti. Na taj način smrt postaje žarišnom točkom i polazištem za egzistencijalna i eshatološka pitanja koja su, bez obzira na to kako pristupamo tematici smrti, ujedno izravno upućene samome životu. U tom se smislu, u prožimanju smrti i života, suptilno susreću pitanja smrti i slobode.

\section{Sloboda kao okosnica eshatoloških promišljanja}

Po Bibliji, težnja za slobodom neizostavno je povezana s onime što podrazumijeva »biti čovjekom«. Štoviše, biblijska nas misao podsjeća na to da je »dar slobode povezan uz izabranje i osloboditeljsko povijesno Božje djelovanje «. ${ }^{28}$ Kao što je smrt usko vezana uz sud, odnosno predstavljena je kao razdjelnica koja mijenja stanje pravednika i bezbožnika, što osobito tematizira knjiga Mudrosti, sličnu ulogu, barem glede eshatona, ima i sloboda. Njezina upravljenost prema dobru ili zlu umnogome odlučuje o konačnom ishodu čovjeka. Katolički nauk također smatra da nakon smrti prestaje mogućnost za donošenjem slobodnih odluka u smislu odlučivanja za ili protiv dobra, odnosno jednostavno Dobra. Egzistencija slobode i njezino izvršenje u grijehu i spasenjskom činu definirana je istina vjere. ${ }^{29}$ Kao što nas smrt upućuje na stvorenost, tako je i sloboda - stvorena sloboda - ona koja nam omogućuje dijalog s Bogom. Sloboda je temeljna odrednica Isusova navještaja (usp. Rim 8,15), gdje je promatrana kao rezultat njegova otkupljenja. Takva sloboda zatim predmnijeva slobodu od grijeha i smrti, odnosno robovanja ovosvjetskim silama. Ona je po svojoj biti eshatološki usmjerena, što znači da je ovdje započela, ali u eshatonu će biti uzdignuta do savršenosti. Time se, teološkim rječnikom izraženo, potvrđuje dijalektička usmjerenost teologije stvaranja i otkupljenja (ordo creationis, ordo redemptionis).

»Povezujući eshatološku raspravu čvrsto s teologijom stvaranja i teologijom saveza, izmičemo zamkama grube materijalizacije i maštovite improvizacije eshatoloških sadržaja, kao i raskolu između individualne i kolektivne eshatologije $[\ldots] . \ll^{30}$

Ovdje, dakle, pretpostavljamo činjenicu slobode neovisno od bilo kakvih filozofskih svjetonazora. Ona je od osobite važnosti za eshatološki ishod ako u obzir uzmemo ćudoredne odluke.

»Pojmovi kao što su 'dobro' i 'zlo', 'odgovornost', 'krivnja', 'zasluga' i 'kazna' bili bi besmisleni kada im u temelju ne bi ležalo iskustvo slobode. $\aleph^{31}$

S druge strane, suvremeni čovjek kao onaj koji je umnogome oslobođen navezanosti na moći različitih tradicija, mora u većoj mjeri (re)konstruirati samoi- 
dentitet koji je u određenoj mjeri u stalnoj mijeni. Životni stil, životne odluke i usmjerenja postaju područja na kojima se vježba sloboda, a da se slobodu ne stavlja u tolikoj mjeri u ontološki kontekst.

»Slobodan život ne treba biti naročito smisleni život, jer pojedinac može odabrati da se svojom slobodom koristi na malo smislene načine. $\ll^{32}$

Konačno, odnos prema životu uvelike reflektira odnos prema smrti. Naučiti živjeti znači naučiti umirati. Prihvatiti život znači prihvatiti smrt. Tek tada u smrti možemo nazrijeti slobodu. Tako bez obzira na sva unutarnja i vanjska ograničenja s kojima se čovjek mora uhvatiti u koštac na putu prema ostvarenju vlastite slobode i oslobođenosti, slobodu možemo promatrati i kao vještinu koju stječemo cjeloživotnim radom na sebi. ${ }^{33} \mathrm{U}$ tom je smislu značajno promišljati o implikaciji i odnosu između slobode i smrti koja zauzima sve više prostora u suvremenom eshatološkom diskursu.

\section{Neki aspekti suvremenog eshatološkog diskursa o smrti i slobodi}

Važna je odrednica suvremenih eshatoloških promišljanja da se iznova nadahnjuju na biblijskim izričajima ${ }^{34}$ i u njihovu dinamizmu traže nadahnuće za svoj iskaz. Također, današnja eshatološka misao nastoji u sebe implementirati rezultate različitih teologija genitivā i njihovu perspektivu uklopiti u svoju globalnu viziju. Tako se, primjerice, teologija nade ne promatra bez relacije s teologijom patnje,$^{35}$ temeljni se religijski pojmovi tumače u širem društveno-političkom kontekstu - tu se može vidjeti utjecaj teologije oslobođenja ${ }^{36}$

28

Ante Mateljan, Tražeći uporište. Teološki radovi, Crkva u svijetu, Split 2000., str. 413.

29

Usp. Heinrich Denzinger, Peter Hünermann (prir.), Zbirka sažetaka vjerovanja, definicija i izjava o vjeri i ćudoređu, Ljudevit Plačko, Karitativni fond UPT Ne živi čovjek samo o kruhu, Đakovo 2002., str. 330-339.

30

Anton Tamarut, »Novo lice posljednjih stvari. Isus Krist, naša nada (1 Tim 1,1)«, Riječki teološki časopis 5 (1997) 1, str. 61-84, ovdje str. 67.

31

Iris Tićac, »Sloboda iz perspektive filozofije i neuroznanosti. Kritika B. Libeta, G. Rotha i W. Singera«, u: Filozofska istraživanja 31 (2011) 2, str. 335-352, ovdje str. 336.

32

Lars Fredrik Händler Svendsen, Filozofija slobode, prev. Zlatko Petir, TIM Press, Zagreb 2014., str. 320 .

33

Ibid., str. 334.

34

Biblija bi »trebala biti duša čitave teologije« (Optatam Totius, 16). Sveto Pismo u tom smislu nije samo normom nego i početnim nadahnućem teološkog razmišljanja, a tome sukladno i svake eshatologije.

35

Klasično mjesto za to predstavlja Moltmannova Teologija nade (Jürgen Moltmann, Teologija nade. Istraživanja o temeljenju i posljedicama kršćanske eshatologije, prev. Željko Pavić, Ex libris, Rijeka 2008.) i još više njegovo djelo Raspeti Bog, gdje se povezanost toga dvoga osobito podcrtava, ali i Metzova djela Memoria passionis (Johann Baptist Metz, Johann Reikertorfer, Memoria passionis. Provokativni spomen u pluralističkom društvu, prev. Stjepan Kušar, Kršćanska sadašnjost, Zagreb 2009.) i Politička teologija (Johann Baptist Metz, Politička teologija. 1967. - 1997., Kršćanska sadašnjost, Zagreb 2004.).

36

Ovdje izdvajam djela jednog od najpoznatijih predstavnika teologije oslobođenja, Jona Sobrina: Jon Sobrino, Christology at the Crossroads. A Latin American Approach, Orbis Books, New York 1978., posebno str. 61-67; 179-235; Jon Sobrino, Izvan sirotinje nema spasenja. Mali utopijsko-proročki ogledi, prev. Roman Karlović, Ex libris, Rijeka 2011. 
i političke teologije $\mathrm{e}^{37}$ - a pozicija neoskolastičke eshatologije gdje su 'ovaj' i 'onaj' svijet strogo razdijeljeni nadiđena je, uz gore navedene utjecaje, suvremenijim i dinamičnijim pristupima koji nastoje, uz biblijske temelje, uklopiti situaciju suvremenog čovjeka, njegove tjeskobe i nade, slobode i čežnje kao polazne točke za poticaj na djelovanje i aktivno građenje Kraljevstva Božjega i prije same smrti. Na čovjeka se više ne gleda kao na pasivnog promatrača koji živi ovaj život prvenstveno čekajući onaj vječni, nego je već sada angažiran, kako u kreiranju vlastitog života, tako i u izgradnji i doprinosu rastu Božjeg kraljevstva.

»Iako treba dobro razlikovati ovozemni napredak od porasta Kristova kraljevstva, ipak je taj napredak, ukoliko može doprinijeti boljem uređenju ljudskog društva, od velike važnosti za Božje kraljevstvo. $\aleph^{38}$

Također, Kraljevstvo Božje, pritom, nije samo onostrana kategorija jer Isus Krist u svojoj osobi predstavlja to Kraljevstvo (autobasileia) i donosi ga na zemlju - u naše prostorno-vremenske okvire, omogućujući da eshaton prodre u ovaj svijet.

»Odgovor na pitanje Božjega kraljevstva jest Sin. U njemu je nadvladan nepremostivi jaz između 'već da' i 'još ne'. U njemu smrt i život, uništenje i bitak stoje zajedno. Križ je most koji premošćuje jaz. [...] Upravo je na taj način Božje kraljevstvo 'nada'. U laboratoriju (tako Ernst Bloch definira svijet) čovjek se nema čemu nadati. Nada postoji samo ondje gdje postoji ljubav. Čovjek se smije nadati zato što se u raspetome Kristu otvorila ljubav koja je pobijedila smrt. « ${ }^{39}$

Kraljevstvo Božje pritom nije samo kristološka nego i eshatološka kategorija. Dakle, ako bismo izdvojili neke od aspekata suvremenog eshatološkog diskursa o smrti i slobodi, to bi svakako bili sljedeći: ponovno vraćanje biblijskim iskazima i načinu promišljanja kao nadahnuću; pozitivno vrednovanje teologija genitivā i njihovo implementiranje na eshatološkom području; dinamično i aktivno gledanje na ulogu čovjeka u ostvarenju i rastu Božjega kraljevstva, koje uvijek iznova upućuje na osobu Isusa Krista kao njezinu bitnu jezgru i refleksiju.

Pored navedenih aspekata, važni su i naglasci prisutni u pojedinačnim teologijama, što će biti vidljivo iz primjera trojice po općem konsenzusu relevantnih teologa (J. Moltmann, K. Rahner, L. Boros), čija će promišljanja ovdje prvenstveno biti prikazana u perspektivi povezivanja smrti i slobode. Njihov je odabir uvjetovan samom temom smrti i slobode, ali i njihovim teološkim, odnosno eshatološkim značajem općenito. To se osobito odnosi na Jürgena Moltmanna i Karla Rahnera, a potom i na Ladislausa Borosa, čiji utjecaj nije u tolikoj mjeri vidljiv u teologiji općenito, ali jest unutar eshatoloških polemika koje se tiču slobode i smrti.

Jürgen Moltmann koristi kriterij nade i u fokus stavlja pojedinca koji svoje kršćanstvo živi prakticirajući ga. Tu u središte dolazi djelatno shvaćanje Kraljevstva Božjega koje pred čovjeka stavlja situaciju prakticiranja slobode. Moltmann je svjestan razdaljine između Božjih obećanja i svijeta u kakvome trenutno živimo, te smatra da kršćanska nada, koja je jednom od središnjih kategorija njegove eshatološke misli, ${ }^{40}$ nije prazna nada, slijepi optimizam, već nam omogućuje da stvarnost vidimo onakvom kakvom jest, da se suprotstavljamo onome što ne odgovara Božjim obećanjima.

»Mir s Bogom znači ne-mir sa svijetom. « ${ }^{41}$

I ne samo da vidi, već u tim teškoćama nada iznova pokazuje svoju snagu: 
»Njegova [Kristova, op. a.] nada postaje životnom snagom upravo tamo gdje više nema nikakve nade. $\ll^{42}$

U tom smislu, Moltmann potiče na to da se odupiremo stanjima koja nisu u skladu s Božjim kraljevstvom, u kojima vlada smrt, a da potičemo ljubav koja podupire to kraljevstvo u kojem već sada možemo anticipirati. ${ }^{43}$ Štoviše, Moltmann je mišljenja da za čovjeka koji je otvoren prema budućnosti i prema svijetu, a pritom je zahvaćen Isusovim uskrsnućem od mrtvih iščekujući ono vlastito, to može imati stimulativan učinak. ${ }^{44} \mathrm{Tu}$ je, također, moguće uočiti korelaciju između kategorija smrti/uskrsnuća i prostora ljudske slobode i djelovanja.

»Bog je postao raspeti Bog kako bismo mi postali slobodnim sinovima Božjim. $«^{45}$

Božja je smrt u izravnoj vezi s ozbiljenjem naše slobode. No, Moltmann razumije Isusovu smrt ne kao 'smrt Boga', već kao »smrt $u$ Bogu «, ${ }^{46}$ naglašavajući pritom trojstvenu dimenziju razumijevanja njegove smrti. Njegova smrt kao krajnja posljedica utjelovljenja nije samo ulazak u čovjekovu konačnost nego je i napuštenost od Boga, kako bi svi koji su napušteni, odbačeni i »umrli«, iskusili svoje zajedništvo s njim. ${ }^{47}$ Nadalje, njegova smrt nije tek nama utješnom činjenicom - »time se eshatološki preobražava metafizička čežnja za beskonačnošću te se ukida s nadom u slobodu Sina Božjeg i slobodu novog neprolaznog stvaranja $\ll^{48}$

Uskrsnuće je novo stvaranje i Kristov križ »oslobađa za prihvaćanje ljudskog života koje je sposobno za patnju i ljubav «. ${ }^{49}$ Upravo u »nadanju protiv nadanja« koje predstavlja uskrsnuće nakon križa, Moltmann smatra da kršćanska nada dokazuje svoju snagu. Time u središta stavlja, pored kategorija Božjih obećanja, čovjeka kao onoga koji u tim obećanjima sudjeluje i baštini ih, ${ }^{50}$ te samu povijest promatra kao poslanje. Tu se prožima svijet nade $\mathrm{i}$ iskustva, a središnji problem kršćanske teologije postaje problem budućnosti. ${ }^{51} \mathrm{U}$ tom smjeru zanimljiv je Moltmnnov stav da je »oslobođenje [Crkve, op. a.] već pretpostavljeno, dok se ona ipak praktično oslobađa samo s društvom u kojem

37

Usp. Johann Baptist Metz, Sulla teologia del mondo, Queriniana, Brescia 1974., str. 79-82; J. B. Metz, Krajolik od krikova.

38

Drugi vatikanski koncil, »Gaudium et spes. Pastoralna konstitucija o Crkvi u suvremenom svijetu (17. XII. 1965.)«, u: Drugi vatikanski koncil, Dokumenti, br. 39.

39

Benedikt XVI. [J. Ratzinger], Eshatologija, str. 72-73.

40

Usp. J. Moltmann, Teologija nade, str. 20

41

Ibid., str. 27.

42

Jürgen Moltmann, »Teologija nade nekad i sad«, prev. Roman Karlović, Bogoslovska smotra 79 (2009) 2, str. 207-221, ovdje str. 211.
43

Ibid., str. 212

44

Usp. J. Moltmann, Raspeti Bog, str. 209.

45

Ibid., str. 217.

46

Ibid., str. 233

47

Usp. ibid., str. 319.

48

Ibid., str. 246.

49

Ibid., str. 349 .

50

Osobito se to odnosi na obećanje uskrsnuća! 51

Usp. J. Moltmann, Teologija nade, str. 22. 
živi«. ${ }^{52}$ I u tom je pogledu Moltmannova misao nadahnuće o promišljanju o relaciji između smrti i slobode.

Edgar Morin je, izrekavši misao »Još jedanput recimo da nas put prema smrti treba odvesti dublje u život, kao što nas put života treba odvesti dublje u smrt.,$^{53}$ pogodio bît teološkog razumijevanja smrti koja, naslanjajući se na biblijsko dinamičko shvaćanje, utire put gledanju na smrt, ne kao na neizbježan usud pojedinca koji ga lišava njegove slobode, već ga baš na tragu te slobode upravlja da uvidi vrijednost života (koliko god on krhak, kratak ili naizgled bezvrijedan bio); da na smrt u konačnici gleda kao na posljednju riječ svojega samoostvarenja.

Na tom je tragu svoj doprinos suvremenom eshatološkom promišljanju u kontekstu govora o smrti i slobodi dao i Karl Rahner. Rahner je o smrti pisao u svojim djelima $O$ teologiji smrti, Temelji kršćanske vjere, Uvod u pojam kršćanstva i Teološki spisi, a na njegov je pristup problematici smrti utjecao Martin Heidegger, čija je predavanja i sam slušao u Freiburgu. ${ }^{54}$

Rahner je kritičan spram tradicionalnog učenja o smrti kao odvajanju duše od tijela ${ }^{55} \mathrm{i}$ ističe važnu misao:

»U smrti se nešto njemu [čovjeku, op. a.] događa kao cjelini, nešto što je, konzekventno, također od esencijalne važnosti za njegovu dušu: njegova slobodna, osobna samoafirmacija i samorealizacija je definitivno ostvarena u smrti. $\ll^{56}$

Smrt je, po Rahnerovu mišljenju, bitno aktivan čin u kojem on samoga sebe posjeduje u slobodi - on se njoj ne izručuje pasivno, nego aktivno, u čini vlastitog samoodređenja. On je promatra u povezanosti sa smrću Isusa Krista; kao što je on sebe slobodno izručio smrti slobodno darujući svoj život i izručujući se Ocu, tako i mi, s njegovim životom kao uzorom na umu, trebamo u smrt ići što je moguće slobodnije, izručujući sami sebe Bogu. Konačno, i sama je teologija slobode određena usmjerenošću naše egzistencije prema smrti, a

»... kroz smrt - ne nakon nje - postoji postignuto konačno važenje čovjekovog slobodno vremenski navršenoga opstojanja. Ono jest to što je postalo, oslobođeno važenje onog nekoć vremenskog koje je nastalo u duhu i slobodi te koje je zato stvorilo vrijeme kako bi bilo, a ne kako bi dalje trajalo u vremenu. $«^{57}$

Svijest o smrti pruža nam mogućnost da živimo - ne usputno, već sa smrću - napuštajući pokušaj apsolutiziranja i prihvaćajući konačnost unutar vlastite slobode. Smrt pritom nije kraj, već dovršenje i ispunjenje.

»Smrt je, u tom kontekstu, izraz slobodnog pristanka na mogućnost nje same u milosnoj povezanosti s Isusom na križu koji slobodno prihvaća smrt. $\ll^{58}$

Smrt je, dakle, po Rahnerovu mišljenju, slobodan ljudski čin, čin čovjeka pojedinca. ${ }^{59}$ On objašnjava:

»Stoga što je smrt permanentno prisutna u cjelokupnosti ljudskog života, biološki i u aktualnom konkretnom iskustvu individualne osobe, smrt je također čin ljudske slobode. Opažamo da čovjek mora umrijeti svojoj smrti u vlastitoj slobodi. On ne može izbjeći smrti koja mu se nameće kao da je djelo njegove slobode. No, kako umire svojoj smrti i kako ju razumijeva, o tome ovisi odluka njegove slobode. Tu on ne podnosi nešto što mu je nametnuto, već što sam izabire. To će reći kako je u činu umiranja svoje ljudske egzistencije čovjek u nužnosti slobodno prihvatiti svoj stav prema smrti. $\ll^{60}$

Dakle, svaki je trenutak života na izvjestan način sučeljavanje i participacija onoga konačnog koji nas tjera da usmjerimo pogled na svoj život, na koji smo način i kako u njemu rabili povlasticu svoje slobode. Cijeli nam život nudi 
mogućnost odluke i prakticiranje slobode, a ne samo trenutak smrti, baš zato jer je smrt neprestano prisutna u životu i s njime se isprepliće.

U određenom je smislu Rahnerovo tumačenje smrti i kritika kršćanske egzistencije jer današnji okvir razumijevanja smrti ne uklapa se u kršćansku eshatologiju koja bi neminovno trebala označavati našu egzistenciju. Stoga, možemo zajedno s Rahnerom postaviti sljedeće pitanje:

»No, možemo li mi današnji iz sebe još uvijek ponovno steći to uvjerenje o trajnosti osobnoga opstojanja unatoč biološkoj smrti, pri čemu bi u ovom trenutku najprije moglo biti svejedno kako ćemo nazvati to uvjerenje, metafizičkom spoznajom, religioznim uvjerenjem ili etičkim postulatom? $\ll^{61}$

\section{Ali i pridružiti mu se u jednom od odgovora:}

»Smrt je po svojoj vlastitoj biti osobno sebe-dovršenje, 'vlastita smrt'. «

Mađarski je teolog Ladislaus Boros slično Rahneru smrt dovodio u korelaciju sa slobodom:

»U smrti se čovjeku otvara mogućnost za prvi potpuno osobni čin; time je smrt pravo mjesto samo-osvještavanja, slobode i opredjeljenja za vječnu sudbinu. ${ }^{63}$

No, bez obzira na početnu sličnost u vidu govora o smrti kao osobnome činu pojedinca čiji je bitan dio sloboda, Boros ipak u diskusiju uvodi sa strane katoličkog nauka problematičnu sintagmu »mogućnost za opredjeljenje «, ${ }^{64}$ kojom želi reći da čovjek u smrti ima mogućnost izabrati ono što će utjeca-

52

J. Moltmann, Raspeti Bog, str. 357.

53

Edgar Morin, Čovjek i smrt, prev. Branka Paunović, Scarabeus-naklada, Zagreb 2005., str. 19.

54

Usp. Herbert Vorgrimler, Understanding Karl Rahner. An Introduction to His Life and Thought, Crossroad, New York 1986., str. 58-59; Zoran Turza, »Povratak smrti u redovito. Teologija smrti Karla Rahnera«, u: Ivan Markešić (ur.), Čovjek i smrt. Teološki, filozofski, bioetički i društveni pristup, Institut društvenih znanosti Ivo Pilar, Hrvatsko katoličko sveučilište - Udruga Posmrtna pripomoć, Zagreb 2017., str. 232-233.

55

Usp. Karl Rahner, On the Theology of Death, prev. Charles H. Henkey, Herder and Herder, New York 1969., str. 17.

56

Ibid., str. 18.

57

Karl Rahner, Temelji kršćanske vjere. Uvod u pojam kršćanstva, prev. Željko Pavić, Ex libris, Rijeka 2007., str. 528.

58

Z. Turza, »Povratak smrti u redovito«, str. 235 .
59

U tom smjeru tumačenja, poznat je i rad Ladislausa Borosa koji u Mysterium mortis također zastupa tezu, slično Rahneru, da je smrt mogućnost osobnog ljudskog čina, mjesto slobode i susreta s Bogom. Usp. Ladislaus Boros, The Mystery of Death, prev. Gregory Bainbridge, Herder and Herder, New York 1965.

60

K. Rahner, On the Theology of Death, str. 85-86.

61

K. Rahner, Temelji kršćanske vjere, str. 529.

62

Karl Rahner, Zur Theologie des Todes, u: Karl Rahner, Sämtliche Werke, sv. 9, Maria, Mutter des Herrn, Regina Pacis (prir.), Verlag Herder, Freiburg 2004., str. 395-417, ovdje str. 412.

63

Ladislaus Boros, Živjeti iz nade, prev. Ljudevit Debeljak, Kršćanska sadašnjost, Zagreb 1970., str. 18

64

Ibid., str. 18; detaljnije o filozofijskome temelju za hipotezu o konačnom opredjeljenju vidi: L. Boros, The Mystery of Death, str. 25-84. 
ti na njegovu konačnu, eshatološku sudbinu jer »tek u smrti postiže čovjek potpuno jedinstvo svoga bića « ${ }^{65}$ Naime, Borosu se predbacivalo da takvim pristupom obezvrjeđuje sve one odluke koje se donose za života, a utječu na konačni usud pojedinca, no, on i sam, pretpostavljajući smjer određenih kritika ${ }^{66}$ pojašnjava svoju poziciju tvrdeći da već sada započinjemo ono što želimo i od budućnosti, odnosno već se sada manjim odlukama i izborima na neki način vježbamo za ono konačno opredjeljenje koje nam donosi smrt. ${ }^{67}$ Ne ulazeći dublje u moralnu i dogmatsku kvalifikaciju Borosove eshatologije, za ovu je temu važno uočiti da je on smrt i slobodu doveo u bliski suodnos te da upravo taj suodnos čini glavni okvir njegova eshatološkog promišljanja kojega gradi oko mogućnosti za opredjeljenje.

Smrt traži pripravu, traži da je živimo već sada. Kršćanstvo uči da sada umiremo (što simbolički započinjemo u sakramentu krsta) i otkrivamo život u Bogu.

»Smrt pripremamo ljubeći je. $\ll^{68}$

U tom je smislu vidljiva veza između smrti i slobode kakvom je shvaćaju neka suvremena promišljanja katoličke eshatologije.

Eshatologija je osobito posljednjih desetljeća promijenila fokus svojeg diskursa, ističući važnost života kao temelj pravilnog razumijevanja smrti. Pritom, sloboda nema samo ulogu usmjeravanja ili određenog moralnog kompasa nego je integralni dio stvorenog čovjeka, nit koja želi ostati usmjerena na ostvarenje vječnosti u dobrome. Sloboda je ono što nas povezuje s Bogom koji stvara, a smrt ona koja nas upućuje na Boga koji ljubi i svojom ljubavlju pobjeđuje smrt - upućuje nas na novo stvaranje.

»Smislena smrt može biti samo smrt života ispunjenog smislom. $\ll^{69}$

Presudno je da eshaton danas u teološkom smislu ne označava samo posljednje stvari koje očekujemo s krajem našeg života nego je njihov predokus već sada osjetan. Sloboda je, pritom, važna odrednica koja, oblikujući ovaj život, ujedno utječe na to kako ćemo sebe razumjeti kroz pitanje smrti koja vodi u onostranost. Sloboda je također ključna u određivanju spram smrti i pozicioniranja našeg života. Dakako, u tom smislu ni smrt ne treba biti smještena u neki romantičarski govor o prolazu u vječnost jer je ona, prije svega, test koji u konačnici stavlja na kušnju i samu slobodu koju čovjek, kao ograničeno biće, prvenstveno realizira kao dijalog s Onim koji jedini doista jest slobodan.

\section{Zaključak}

Smrt i sloboda pripadaju temeljnim filozofskim i teološkim kategorijama. Intencija ovoga članka bila je prvenstveno istražiti odnos tih dviju kategorija u kontekstu nekih aspekata suvremenih eshatoloških promišljanja, osobito se naslanjajući na dosege biblijskih iskaza kojima se eshatologija nadahnjuje te nekim suvremenim razmišljanjima o odnosu tih dviju kategorija, osobito u misli Rahnera, Moltmanna i Borosa.

Veza između smrti i slobode najvidljivija je u kontekstu moralnosti i teološkog tumačenja smrti kao posljedice grijeha. Jedno od stožernih teoloških definicija smrti jest da je smrt posljedica grijeha, a grijeh se događa zlouporabom slobode. S druge strane, čovjeka u kontekstu njegove stvorenosti promatramo kao slobodno, kreativno, ali i konačno biće kojemu je smrt vlastita. Ona, osim što proizlazi iz grijeha, također proizlazi iz činjenice da je čovjek dio stvo- 
renoga svijeta, dio prirode u kojemu je smrt i prolaznost dijelom prirodnoga ciklusa.

Konstatirali smo da sve o čemu čovjek promišlja i preispituje u vezi eshatona, rezultat je postojanja smrti. Smrt i sloboda predstavljaju neizostavan okvir eshatološkog promišljanja. Članak se bavio smrću kao jezgrom eshatologije jer svako eshatološko pitanje započinje s njome i činjenica čovjekove smrtnosti ujedno predstavlja i teološko pitanje. No, s druge strane, bilo je vidljivo da je središnji biblijski pojam život, a ne smrt. Ipak, u konkretizaciji eshatoloških sadržaja u Starome zavjetu važnu ulogu zauzima pojam šeola, koji predstavlja objektivizaciju iskustva o smrti. U nastojanju povezivanja kategorija smrti i slobode, uočili smo da je povijesno oduzimanje slobode izraelskom narodu bilo poticaj na razmišljanje o tome imaju li svi isti kraj i hoće li onostranost biti mjestom očitovanja Božje pravednosti. Konačno, Biblija uglavnom smrti pristupa kao prirodnom fenomenu, ali izbjegava svođenje teologije na antropologiju jer, iako su starozavjetni pisci shvaćali smrt kao nešto naravno, postoje i tekstovi koji smrt vezuju uz grijeh. Promišljanja o smrti se potom produbljuju u Novome zavjetu, osobito u smrti Boga na križu. Njegova je smrt protest protiv svih vrsta ubijanja i stanja nedostojna čovjeka: grijeha, bolesti, marginaliziranja, usamljenosti. Smrt Isusa Krista zadnja je posljedica njegova utjelovljenja.

Smrt je, dakle, antropološka danost i zadanost, no kako umrijeti postaje slobodnim izborom. Nakon smrti prestaje mogućnost slobodnih odluka za ili protiv dobra, a sloboda je i temelj Isusova navještaja. Ona se promatra kao rezultat njegova otkupljenja u vidu slobode od grijeha i smrti. Odnos prema životu odražava odnos prema smrti jer nas prihvaćanje života uči prihvaćanju umiranja i tek u tom prihvaćanju možemo pronaći prostor za djelatno shvaćanje slobode.

Što se tiče aspekata suvremenog eshatološkog diskursa, on je usmjeren na ponovno iščitavanje biblijskih iskaza kao svojem nadahnuću; pozitivnom vrednovanju teologija genitivā i njihovom implementiranju na eshatološkom području; dinamičnom i aktivnom pristupu ulozi čovjeka u ostvarenju i rastu Božjega kraljevstva. Kraljevstvo Božje čovjeka izaziva na prakticiranje slobode i njezino ozbiljenje. Taj je aspekt posebno istaknuo Moltmann, povezujući smrt Isusa Krista s našom slobodom, te njegovim uskrsnućem kao onim što nas oslobađa za život. Moltmann u središtu svoje eshatologije povezuje nadu i patnju, osobito na tragu biblijski nadahnute teologije križa. Rahner,

65

L. Boros, Živjeti iz nade, str. 20.

66

Usp. Ivan Pavao II., Sjaj istine = Veritatis splendor. Enciklika: o nekim temeljnim pitanjima moralnog naučavanja Crkve, prev. Mate Maras, Morana Čale-Knežević, Kršćanska sadašnjost, Zagreb 1998., br. 65; Marijan Valković, Doprinosi koncilskoj moralnoj teologiji, Kršćanska sadašnjost, Zagreb 2009. str. 275-279. Valković dobro razjašnjava problematiku oko temeljnog opredjeljenja (optio fundamentalis) kojega razlikuje od optio finalis, ističući da je grešnik i pod grijehom uvijek u mogućnosti odgovoriti na Božji poziv i milost, a opet naglašavajući da svaka naša radnja određuje, ali ne definira posvema naš etos. Usp. M. Valković, Doprinosi koncilskoj moralnoj teologiji, str. 278-279.

67

Usp. L. Boros, Živjeti iz nade, str. 22-24.

68

François-Xavier Durrwell, Krist, čovjek $i$ smrt, prev. Adalbert Rebić, Kršćanska sadašnjost, Zagreb 2009., str. 61.

69

Ante Vučković, »Smislenost smrti. Egzistencijalističko, židovsko i kršćansko gledište«, u: Nedjeljko Ante Ančić, Nikola Bižaca (ur.), Pristupi umiranju $i$ smrti, Crkva u svijetu, Split 1999., str. 31-56, ovdje str. 56. 
s druge strane, smrt promatra kao čin vlastitog samoodređenja. I ne samo u smrti kao finalnom činu nego i u svakom trenutku života možemo prihvaćati smrt(nost). Naslanjajući se na njegovu teoriju o smrti kao svjesnom činu pojedinca, čovjek može u najvećoj tjeskobi i zarobljenosti svojom krhkošću i prolaznošću, imati mogućnost iznaći način da daruje samoga sebe i u tom 'gubljenju' pronađe smisao i u toj naizglednoj zarobljenosti konačnim, pronađe oslobođenje. Na tom tragu i Boros tematizira kompleksan (i kritiziran!) pojam »mogućnosti opredijeljenja«, ističući smrt kao mjesto samo-određenja i svojevrsne slobode koja se nastoji u životu prakticirati. U tom smislu, život i smrt prestaju biti dvije suprotnosti, oni se prožimaju.

Premda nam se početno pitanje o tome jesmo li slobodni umrijeti može učiniti pomalo neobičnim i nepotrebno provokativnim jer je razvidno da moramo umrijeti i da tu slobodi nema nekog mjesta, opet možemo odgovoru drugačije pristupiti. Ovdje nije odlučujući faktor ograničenje osobne slobode koje ona ionako uvijek posjeduje, nego predstavlja li smrt ograničenje za ostvarivanje te slobode. Naslanjajući se na određene naglaske suvremene eshatologije, možemo zaključiti da nas prakticiranje slobode uči životu, a nakon što tu lekciju (barem donekle) svladamo, postajemo i otvoreniji slobodnije primiti smrt kao onu koja nas ima uništiti da bismo bili iznova stvoreni, koja nas ispražnjava da bismo zadobili novu puninu, te da tom bolnom procesu ništenja možemo slobodno prići da bismo mogli biti preobraženi. Vođeni tom argumentacijom, zaključno možemo ustvrditi da su sloboda i smrt doista povezani, da tvore ono specifično ljudsko i da nam implicitno otvaraju horizont prema onostranosti.

\title{
Iva Mršić Felbar
}

\section{Are We Free to Die?}

Some Aspects of Discussion about Death and Freedom in the Contemporary Catholic Eschatology

\begin{abstract}
The paper explores the problem of death as a central issue of every eschatology, including the Catholic one. Death as a phenomenon and anthropological fact shapes the beginnings of the Old Testament' Eschatology, sharpening its statement in the New Testament' theology crucis. During the history of theology, the theology of death remained within the frame of its interpretation as a consequence of sin and unwanted fate, whereby its positive connection to freedom was left out. Only thanks to some of the contemporary approaches that place death in direct relation to freedom (Moltmann, Rahner, Boros), observing it as a conscious act of an individual, both death and freedom, although at first opposed, become the categories that, theologically observed, transform themselves. In conclusion, the paper attempts to answer the question regarding freedom to die, in the light of some contemporary eschatological debates, and to place the awareness of death in the context of freedom and life, and not as their opposition.
\end{abstract}

\section{Keywords}

eschatology, death, freedom, old testament, human being 